\title{
Potensi konflik dan pembentukan modal sosial: belajar dari sebuah desa transmigran di Kalimantan Timur
}

\author{
Conflict potential and social capital construction: \\ a case study of a transmigrant village in East Kalimantan
}

\author{
Sukapti Wartiharjono \\ Fakultas Ilmu Sosial dan Politik, Universitas Mulawarman \\ Jalan Muara Muntai, Kampus Gunung Kelua, Samarinda, Kalimantan Timur \\ E-mail:vkapti89@gmail.com
}

\begin{abstract}
Conflicts caused by differences in cultural backgrounds and competition over natural resources among social groups in the project areas of transmigrations in Indonesia are not uncommon occurrences. This paper seeks to explore two aspects pertaining to this issue: (1) social conflict potentials among transmigrant communities particularly those between local transmigrants and the inter island transmigrants; and (2) the formation of social capital as an instrumental power in achieving and sustaining harmonious social relationship in the area in question. The research on the two subjects was a qualitative field research. In-depth interview and observation were employed in gathering data. The research had led to the finding that the conflict potentials in the observed transmigrant area were related to land distribution among transmigrant households and access to economic resources. Nonetheless, the conflict potentials did not inhibit the formation of social capital that bound all the members of the society. The result of the observation showed that a social trust has been constructed among the transmigrant settlers based on the value of cooperation or working together formutual benefit both in the daily interactions in the settlement area and in the plantation management activities. The prevalent social trust has prevented open conflict from breaking out among different ethnic social groups and hencecreated harmonious social relations.
\end{abstract}

Keywords: conflict potential, social capital, transmigrants, ethnic group

\begin{abstract}
Abstrak
Transmigrasi tidak jarang menimbulkan konflik di daerah tujuan, karena perbedaan latar budaya dan akses sumber daya antar kelompok sosial. Artikel ini akan membahas dua hal yakni: (1) potensi konflik sosial dalam masyarakat transmigran, terutama antara transmigran lokal dan transmigran pendatang; dan (2) terbentuknya modal sosial sebagai kekuatan yang berguna untuk mempertahankan kelangsungan kehidupan bersama di daerah tujuan transmigrasi. Kajian penelitian dilakukan dengan pendekatan kualitatif, menggunakan metode wawancara mendalam dan observasi untuk menghimpun data. Wawancara mendalam yang dipandu dengan interview guide dilakukan dengan informan para transmigran yang berasal dari transmigran lokal Suku Paser maupun dengan transmigran pendatang yang berasal dari Jawa. Observasi partisipasi dilakukan untuk melihat aktivitas keseharian atau kehidupan sosial warga. Kajian ini menemukan bahwa potensi konflik yang ada terkait dengan sejarah penyediaan dan distribusi lahan transmigran dan dinamika akses pada sumber daya ekonomi, namun potensi konflik tersebut tidak menghambat terbentuknya modal sosial yang mengikat semua anggota masyarakat. Tercipta kepercayaan (trust) yang didasari pada nilai-nilai kebersamaan dan tolong menolong antar keluarga transmigran baik di dalam lingkungan pemukiman maupun aktivitas pengelolaan perkebunan. Keberadaan modal sosial ini mampu menangkal terjadinya konflik terbuka antar kelompok sosial berbeda suku bangsa, sehingga tercipta hubungan sosial yang harmonis.
\end{abstract}

Kata kunci: potensi konflik, modal sosial, transmigran, suku bangsa

\section{Pendahuluan}

Transmigrasi merupakan bentuk mobilitas spasial atau migrasi penduduk yang digagas pemerintah dengan tujuan salah satunya untuk membangun daerah tujuan transmigrasi. Namun program transmigrasi berpotensi menimbulkan konflik di daerah tujuan. Perbedaan perilaku dan latar belakang kebudayaan antara warga transmigran yang didatangkan dari daerah lain dengan warga lokal tidak 
jarang menimbulkan ketegangan. Clauss et al. (1988) menyatakan bahwa para transmigran harus membangun hubungan sosial baru atas dasar heterogenitas dan pluralitas yang berkaitan dengan bahasa, unsur-unsur budaya, adat istiadat, dan juga praktik keagamaan untuk menjaga hubungan harmonis di tempat yang baru. Heterogenitas dan pluralitas tersebut dapat menyebabkan fragmentasi antar kelompok sosial dan pada gilirannya menimbulkan konflik. Namun, akses dan kontrol terhadap sumber daya, terutama sumber daya ekonomi dan politik antara transmigran dan warga/transmigran lokal juga menjadi pemicu utama ketegangan dan konflik yang dapat merusak kelangsungan hidup bersama.

Fenomena penolakan dari masyarakat di daerah tujuan atas rencana program transmigrasi masih terjadi hingga saat ini seperti yang diberitakan di media massa (Kompas.com, 17 September 2012; Ucanews.com, 20 Mei 2015; Beritasatu.com, 25 Mei 2015; Pontianakpost, 28 Agustus 2016). Di Kalimantan, konflik sosial dan isu penolakan terhadap rencana program transmigrasi oleh beberapa kalangan masih terjadi bahkan pernah dilakukan petisi penolakan yang ditujukan ke pemerintah. Tidak hanya di Kalimantan, penolakan terhadap program transmigrasi terjadi di beberapa daerah yang dijadikan sebagai tujuan program transmigrasi seperti di Sulawesi dan Papua. Alasan penolakan pada umumnya berkaitan dengan keterbasan sumber daya lahan di tempat tujuan dan keadilan bagi masyarakat lokal. Dengan demikian, potensi konflik antara pendatang dan warga lokal di daerah transmigrasi merupakan fenomena yang selalu aktual untuk didiskusikan dalam konteks Indonesia.

Potensi konflik sosial selalu terkandung di setiap masyarakat, namun proses sosial antara transmigran dengan penduduk lokal dapat juga mengarah pada hubungan sosial yang harmonis. Interaksi sosial antar individu selama tinggal bersama di lokasi transmigrasi memungkinkan berkembangnya modal sosial. Fukuyama (1995) menyatakan bahwa modal sosial didasarkan pada sikap saling percaya. Modal sosial adalah kapabilitas yang muncul dari kepercayaan umum di dalam masyarakat atau elemen-elemen tertentu dari masyarakat, sehingga mampu menghasilkan kerjasama antar elemen untuk mencapai kemajuan bersama. Hal tersebut merupakan dimensi budaya yang dapat menentukan keberhasilan pembangunan ekonomi dan sosial. Menurut Putnam (Ahmadi 2003), modal sosial terdiri dari aspek-aspek utama dari suatu organisasi sosial, seperti kepercayaan, norma-norma, jaringanjaringan yang dapat meningkatkan efisiensi dalam suatu masyarakat melalui fasilitas bagi tindakantindakan yang terkoordinasi.

Penelitian tentang modal sosial telah banyak dilakukan, seperti penelitian Wafa (2003) yang menunjukkan bahwa keberadaan modal sosial pada kelompok tani Mardi Utomo lebih kuat daripada modal sosial pada kelompok PKK. Keberadaan modal sosial kelompok tani Mardi Utomo melekat dalam struktur sosial dan mampu dimanfaatkan dalam menjalankan kegiatan kelompok. Sebaliknya, kelompok PKK tidak mampu memanfaatkan trust sebagai penyangga modal sosial untuk memajukan kelompok. Penelitian Ahmadi (2003) menunjukkan bahwa kapital sosial dapat mempengaruhi kemajuan dan kesejahteraan ekonomi suatu komunitas. Penelitian yang dilakukan terhadap komunitas orang Madura di NTB menemukan bahwa modal sosial memainkan peranan penting dalam memfasilitasi koordinasi dan kerjasama yang saling menguntungkan antara sesama orang Madura di Sumbawa.

Berdasar latar empiris dan teoritis tersebut, kajian ini akan melihat proses sosial antara transmigran pendatang dengan transmigran/warga lokal selama tinggal atau hidup bersama. Pertanyaan yang akan dijawab dari penelitian ini adalah potensi konflik seperti apa yang ada di antara kelompok transmigran pendatang dengan transmigran/warga lokal di Desa Sawit Jaya, Kecamatan Long Ikis. Bagaimana modal sosial terbentuk dari interaksi sosial antar kelompok transmigran, sehingga mampu menguatkan keharmonisan kehidupan bersama hingga saat ini? Diasumsikan bahwa potensi konflik yang ada dalam setiap masyarakat tidak akan berkembang menjadi konflik terbuka apabila suatu masyarakat mampu membangun modal sosial berupa nilai-nilai atau mekanisme sosial yang mempersatukan hingga terbentuk jalinan kerjasama antar anggota atau kelompok masyarakat. 


\section{Metode Penelitian}

Penelitian ini menggunakan perspektif fenomenologi yang akan menuntun peneliti untuk memahami interaksi sosial dengan cara berpijak pada realitas empiris yang hidup dalam kesadaran dan pengalaman hidup masyarakat. Ahimsa (2012) menjelaskan tentang kesadaran dalam perspektif fenomenologi tersebut sebagai kesadaran yang diarahkan pada dunia kehidupan. Kesadaran yang terbentuk di antara mereka bersifat sosial atau dimiliki secara bersama. Pengalaman pribadi dalam dunia tersebut beserta pengalaman orang-orang lain merupakan pengalaman bersama. Mengikuti perspektif ini, diperlukan pendekatan penelitian lapangan yang mampu melihat sudut pandang yang hidup dalam kesadaran setiap anggota masyarakat. Penelitian akan diarahkan untuk menggali pengalaman riil selama berinteraksi antar kelompok sosial berbeda etnis. Penelitian lapangan dilakukan di Desa Sawit Jaya, Kecamatan Long Ikis, Kabupaten Paser, Kalimantan Timur. Penduduk asli Kabupaten Paser disebut sebagai Suku Paser. Menurut pandangan mereka sendiri, mereka merupakan bagian dari kelompok Suku Dayak yang merupakan penduduk asli Kalimantan. Singarimbun (1994) mengutip pendapat Sellato, bahwa 90\% penduduk Melayu Kalimantan adalah keturunan Dayak. Pengumpulan data dilakukan dengan wawancara dan observasi partisipasi, serta kajian literatur. Wawancara mendalam yang dipandu dengan interview guide dilakukan dengan informan, yakni para transmigran yang berasal dari transmigran lokal yang beretnis Paser maupun dengan informan transmigran pendatang yang berasal dari Jawa. Observasi partisipasi dilakukan untuk melihat aktivitas keseharian atau kehidupan sosial warga. Penelusuran literatur dilakukan untuk menemukan dan menguatkan data dan konsep yang diperlukan dalam kajian ini.

Data yang dihimpun pada umumnya berupa pernyataan, pendapat dan cerita tentang suatu peristiwa atau pengalaman sehari-hari. Analisis data dilakukan dengan cara penelaahan seluruh data yang telah dihimpun dengan berbagai teknik, kemudian tahap reduksi data dilakukan dengan cara memilah-milah data yang sesuai dan yang tidak. Selanjutnya dilakukan abstraksi data dengan menyusun data dalam satuan atau tema-tema, untuk kemudian diinterpretasi di mana satuan-satuan data dihubunghubungkan untuk menjelaskan sebab, potensi konflik, serta modal sosial masyarakat.

\section{Hasil Penelitian dan Pembahasan}

Desa Sawit Jaya yang menjadi lokasi penelitian ini merupakan salah satu desa dari wilayah Kecamatan Long Ikis, Kabupaten Paser. Sebagian desa-desa di wilayah Kecamatan Long Ikis berada di daerah pesisir dan sebagian desa lainnya berada di daratan yang terletak di perdesaan/pedalaman. Desa Sawit Jaya termasuk daerah pedalaman (bukan pesisir) yang beriklim tropis basah dan tidak memiliki perbedaan musim yang jelas antara musim kemarau dan musim penghujan. Kecepatan angin bertiup sedang dan suhu rata-rata sepanjang tahun 26 derajat celcius, dengan rata-rata curah hujan $189,72 \mathrm{~mm}$. Kondisi topografis Desa Sawit Jaya dan desa-desa sekitarnya secara umum landai hingga bergelombang atau bergunung-gunung (berbukit-bukit). Iklim dan kondisi topografis desa pedalaman ini dianggap cocok untuk daerah pertanian/perkebunan.

Desa Sawit Jaya termasuk suatu desa baru yang pada awalnya merupakan desa "bentukan" dari Unit Pemukiman Transmigran yang dimukimkan antara tahun 1983-1986. Para transmigran sebagian besar didatangkan dari Jawa dan sebagian kecil merupakan transmigran lokal Suku Paser. Pada kenyataannya, proses memukimkan transmigran membutuhkan waktu lebih dari tiga tahun, karena banyaknya transmigran yang tidak betah dan meninggalkan lokasi transmigrasi. Proses penggantian para transmigran memerlukan waktu lama. Dikatakan oleh sebagian warga bahwa kondisi atau infrastruktur dan pemukiman yang masih sangat buruk pada masa-masa awal dimukimkan menjadi penyebab dari tidak betahnya transmigran di tempat baru.

Secara umum, transmigran diberikan fasilitas rumah, lahan pangan, dan lahan pertanian dan perkebunan, jaminan hidup, dan sarana kebutuhan hidup lainnya. Pemukiman dibangun sedemikian rupa menjadi tampak tertata, teratur, dan seragam antar rumah. Jatah rumah transmigran terbuat dari kayu baik dinding dan lantainnya, sedangkan atap berupa seng. Rumah-rumah transmigran dibangun 
berdekatan dan berada di areal terpisah dari areal perkebunan sawit. Pemukiman dibagi ke dalam blok-blok, dan dibangun di sepanjang jalan antar blok menyesuaikan kondisi topografis yang berbukit-bukit. Jalan desa yang menghubungkan pemukiman antar blok satu dengan blok lainnya pada umumnya dibuat membentuk garis lurus, meskipun topografinya dibiarkan bergelombang. Infrastruktur jalan di dalam desa hingga saat penelitian ini dilakukan tahun 2015-2016 masih berupa jalan makadam, yakni jalan yang terbuat dari susunan batu dan pasir.

Para transmigran sengaja didatangkan dan dimukimkan untuk menjadi petani komoditas perkebunan sawit dengan pola PIR. Artinya, para transmigran atau petani sawit di Desa Sawit Jaya merupakan petani binaan/mitra dari perusahaan perkebunan besar. Pada saat itu perkebunan komoditas sawit dikembangkan untuk pertama kali di wilayah Kabupaten Paser. Sebagai pengembangan komoditas perkebunan sawit pertama kali di Kalimantan Timur, program PIR transmigrasi perkebunan di Desa Sawit Jaya mendapat dukungan kebijakan dan teknis yang cukup baik dari pemerintah pusat maupun daerah untuk menjamin keberhasilannya. Para transmigran disiapkan untuk mengembangkan mode produksi perkebunan sawit dan meninggalkan mode produksi pertanian sawah dan perladangan berpindah yang digeluti sebelumnya karena dianggap tradisional dan tidak ekonomis.

Masyarakat Paser, seperti masyarakat asli Kalimantan pada umumnya dicirikan dengan sistem pertanian perladangan berpindah (Dove 1988). Sistem pertanian perladangan ini memerlukan beberapa lahan di lokasi yang berbeda dan masing-masing lokasi ladang ditanami secara bergantian (rotasi). Ketika lokasi ladang yang satu sedang dikerjakan atau ditanami, sebagian lokasi ladang yang lain dibiarkan tidak ditanami dalam waktu bertahun-tahun lamanya untuk mengembalikan kesuburan tanah. Mereka menanam padi, jagung dan sayur mayur untuk memenuhi kebutuhan subsisten. Kebutuhan uang tunai dipenuhi dengan menanam tanaman perkebunan, seperti rotan, karet dan lada. Selain itu, tanaman perkebunan buah-buahan, seperti langsat, rambutan, durian, serta buah-buah lokal maupun hasil hutan lainnya menjadi sumber penghasilan tambahan. Dengan demikian, kehidupan ekonomi masyarakat Paser ditopang oleh sumber daya alam hutan.

Mata pencaharian utama warga Desa Sawit Jaya pada saat ini adalah petani perkebunan sawit (pekebun). Saat penelitian ini dilakukan telah terjadi diferensiasi ekonomi dilihat dari kepemilikan lahan dan status sosial ekonomi antar warga. Pada awalnya peserta transmigrasi mendapat sarana produksi dan fasilitas yang sama atau seragam. Seiring perjalanan waktu, kepemilikan lahan perkebunan antar warga transmigran berbeda-beda. Sebagian besar transmigran merupakan pekebun kecil/miskin dengan luas lahan perkebunan sekitar dua hektar, namun ada sebagian kecil warga yang mampu memiliki lahan yang lebih luas, yakni antara empat hingga puluhan hektar kebun sawit. Lahan perkebunan merupakan basis material hampir semua warga desa. Perbedaan kepemilikan faktor produksi kebun/lahan menunjukkan adanya diferensiasi ekonomi yang cukup menonjol antara patani kaya dan petani miskin.

Komposisi penduduk berdasar etnis menunjukkan bahwa penduduk asli yang disebut orang Paser, di wilayah Kecamatan Long Ikis hanya sebesar 21,37\%, selebihnya kurang lebih $78 \%$ penduduk berasal dari daerah atau suku bangsa lain (pendatang). Pola yang sama juga terjadi di Desa Sawit Jaya, di mana penduduk yang berasal dari suku Paser hanya berkisar 30\% dari jumlah penduduk yang berasal dari suku bangsa lain atau pendatang. Komposisi penduduk yang bersifat heterogen berdasar etnis memberikan karakter tersendiri bagi hubungan antar warga masyarakat. Dari sisi agama, komposisi penduduk cenderung homogen di mana sebagian besar anggota masyarakat baik dari pendatang maupun lokal beragama Islam, dan hanya sebagian kecil beragama Kristen dan Katolik.

\section{Potensi konflik dalam masyarakat transmigran}

Secara umum, kehidupan sosial di Desa Sawit Jaya cukup harmonis, paling tidak hingga saat penelitian ini dilakukan hubungan sosial yang tercipta di antara warga transmigran terjalin dengan baik. Namun, poses sosial selama sekitar 30 tahun sejak Desa Sawit Jaya dibentuk dengan didatangkannya transmigran dari Jawa pada tahun 1983-1986 dibayangi dengan adanya potensipotensi konflik ataupun konflik yang memerlukan mekanisme sosial untuk mengelolanya supaya tetap 
harmonis. Hal ini penting dicermati mengingat proses sosial tidak akan pernah berhenti pada suatu kondisi tertentu, melainkan bersifat dinamis sebagai respon atas perubahan internal maupun eksternal masyarakat yang selalu terjadi.

Konflik yang terjadi di Desa Sawit Jaya dan juga desa-desa lain di sekitarnya dapat dibedakan menjadi dua, yakni konflik vertikal dan horisontal. Sumber konflik utama di Desa Sawit Jaya yang disoroti dalam penelitian ini adalah masalah perampasan sumber daya lahan milik masyarakat lokal, berupa area pemukiman, perladangan dan hutan cadangan bagi perluasan aktivitas berladang, yang dilakukan oleh pemerintah. Proses perampasan lahan tersebut dapat dilihat sebagai bagian dari proyek teritorialisasi, yakni berupa penataan wilayah dan masyarakat hingga pelosok perdesaan yang dilakukan oleh pemerintah atas nama pembangunan (Li 2002). Hal tersebut telah terjadi sekitar tiga dekade lalu, namun persoalan tersebut menyisakan ingatan kolektif tentang ketidakadilan bagi masyarakat lokal dan berpotensi menimbulkan konflik dalam masyarakat hingga saat ini.

Konflik vertikal adalah konflik yang melibatkan pihak-pihak dalam posisi yang tidak sejajar, seperti konflik antara pemerintah, warga (petani), dan perusahaan. Sumber konflik vertikal yang utama di desa-desa di wilayah Kecamatan Long Ikis adalah persoalan tanah dan lahan yang diambil alih serta dialih fungsikan menjadi area perkebunan sawit oleh pemerintah yang berkolaborasi dengan perusahaan. Warga lokal, termasuk di dalamnya warga Desa Sawit Jaya yang berasal dari Suku Paser terlibat persengketaan dengan perusahaan dan pemerintah. Lahan yang mereka gunakan untuk berladang dan bermukim diserobot oleh pemerintah dan diberikan kepada perusahaan perkebunan besar baik swasta maupun negara untuk pembangunan perkebunan. Serangkaian tindakan penolakan atau perlawanan kecil-kecilan dilakukan oleh masyarakat lokal ketika itu, namun mereka harus mengalah dan menerima kenyataan bahwa lahan dan sumber penghidupan mereka telah hilang. Politik masa Orde Baru tidak memungkinkan masyarakat lokal mengalahkan pemerintah. Konflik yang pernah terjadi tersebut merupakan memory collective yang tidak mudah dilupakan dan menghasilkan kekecewaan serta ketidakpercayaan berkepanjangan kepada pemerintah dan perusahaan besar. Ketika memasuki era reformasi, terjadi rangkaian aksi kolektif dari masyarakat lokal di 10 desa di wilayah Long Ikis yang menuntut pengembalian lahan masyarakat dari perusahaan perkebunan. Aksi pendudukan lahan perkebunan besar oleh masyarakat lokal dan proses negosiasi berhasil mengembalikan sebagian lahan masyarakat lokal. Hingga sekarang, persoalan terkait tuntutan pengembalian lahan oleh masyarakat kepada perusahaan masih belum selesai.

Konflik atau pertentangan horisontal adalah konflik sosial yang melibatkan pihak-pihak dalam posisi yang sejajar. Pemicu konflik dan ketegangan antara transmigran lokal dan transmigran dari Jawa terkait dengan pengadaan lahan yang diperuntukkan bagi proyek transmigrasi. Diawali dari pengambilalihan lahan milik masyarakat lokal oleh pemerintah untuk proyek transmigrasi, di mana proses tersebut tanpa persetujuan warga lokal sebagai pemilik lahan. Bahkan, masyarakat lokal tidak mendapatkan ganti rugi atas lahan dan tanam tumbuh di atas lahan tersebut. Upaya mempertahankan dan meminta ganti rugi pun tidak membuahkan hasil.

Lahan yang diambil oleh pemerintah hasil penyerobotan lahan milik warga lokal diredistribusikan kepada transmigran yang berasal dari Jawa maupun daerah lain. Masing-masing rumah tangga transmigran mendapatkan lahan pokok untuk pertanian seluas dua hektar per rumah tangga, lahan pangan seluas 0,25 ha serta lahan untuk rumah dan pekarangan seluas 0,25 ha. Transmigran lokal yang berasal dari warga sekitar juga mendapat hak atas luas lahan yang sama. Pemberian hak yang sama antara transmigran dari Jawa dan transmigran lokal dianggap sebagai bentuk ketidakadilan bagi masyarakat lokal karena sumbangan warga lokal demi program transmigrasi jauh lebih besar dibandingkan dengan transmigran lain. Masyarakat lokal merasa harus membayar harga yang terlalu besar bagi keikutsertaannya sebagai transmigran, sedangkan transmigran dari luar daerah dianggap paling diuntungkan dari proyek transmigrasi, sehingga hal itu menimbulkan kecemburuan.

Dari kasus tersebut tampak bahwa pemicu konflik horisontal bukan berasal dari interaksi sosial keseharian antara transmigran pendatang dan lokal, melainkan akibat dari berlakunya kekuasaan negara yang memarginalkan masyarakat lokal. Kasus penyerobotan lahan milik masyarakat adat oleh 
negara demi pembangunan merupakan tindakan yang didukung oleh undang-undang dan kasus ini sering terjadi pada masa Orde Baru (Fauzi 1999). Hal itu menyebabkan masyarakat lokal kehilangan mata pencaharian, miskin, dan menimbulkan generasi yang bingung dengan suasana baru (Wibowo et al. 2008). Konflik nyata terkait penyediaan lahan untuk proyek transmigrasi berangsur-angsur berkurang intensitasnya, meskipun pengalaman ketidakadilan yang dirasakan warga lokal tidak akan hilang dari ingatan kolektif mereka.

Program transmigrasi memaksa para transmigran lokal untuk tinggal bersama di lokasi yang sama dengan transmigran yang berasal dari Jawa, meskipun di antara mereka tersimpan potensi konflik yang cukup besar terkait ketidakadilan redistribusi lahan di masa lalu. Selain itu, dalam kehidupan bersama perbedaan kebudayaan terutama perbedaan perilaku dalam pengelolaan lahan dan cara mengakses sumber daya menimbulkan munculnya stereotipe-stereotipe negatif. Saling melabelkan citra negatif terhadap kelompok sosial dari etnis lain tersebut merupakan bentuk konflik tersembunyi, namun pada umumnya masing-masing kelompok transmigran yang berbeda etnis mencoba menekan supaya stereotipe negatif yang mereka percayai tersebut tidak merusak hubungan sosial di antara mereka. Secara umum, hubungan sosial antar warga atau kelompok warga cukup terjalin dengan baik.

\section{Nilai gotong royong sebagai landasan pembentukan modal sosial}

Kajian lapangan ini menemukan bahwa nilai gotong royong yang dimiliki oleh transmigran dari Jawa maupun transmigran lokal Suku Paser menjadi basis utama dari pembentukan modal sosial dalam komunitas transmigrasi. Kedua kelompok sosial mendukung nilai sosial yang sama yakni nilai gotong royong dan saling tolong menolong. Nilai tersebut memberikan penghargaan yang tinggi pada sikap dan tindakan-tindakan untuk saling memberikan bantuan antar sesama sebagai kunci dalam hidup bermasyarakat. Nilai sosial gotong royong dan tolong menolong telah mereka miliki sejak sebelum bermukim di area transmigrasi, dan selanjutnya nilai tersebut dibawa dan dipertahankan di lokasi transmigrasi.

Masyarakat Suku Paser mempraktikkan hidup bergotong royong dalam aktivitas berladang yang telah dilakukan secara turun temurun. Secara berkelompok mereka memilih dan membuka lahan di area yang sama atau lokasi yang saling berdekatan. Pilihan akan area ladang yang saling berdekatan bertujuan untuk menekan atau mengurangi risiko tanaman padi dari serangan hama. Di sisi lain, cara tersebut dipilih agar memudahkan dalam memenuhi kebutuhan atau pengorganisasian tenaga kerja yang terbatas. Sistem gotong royong digunakan dalam melakukan persiapan lahan hingga lahan siap ditanami, penyemaian bibit, pemeliharaan, serta pemanenan hasil. Tidak dikenal sistem upah dalam kegiatan tersebut. Kondisi alam dan keterbatasan tenaga kerja mengkondisikan para peladang menginternalisasi nilai gotong royong dalam kehidupannya. Dalam pemanfaatan hasil hutan non kayu, misalnya madu, masyarakat Suku Paser juga menjunjung tinggi nilai kerjasama dan kebersamaan. Pemetikan madu dilakukan secara kolektif antar anggota masyarakat dengan cara pergi ke hutan secara bersama-sama, selanjutnya hasil madu dibagi rata ke semua anggota yang ikut serta dalam pemanenan.

Kehidupan sosial transmigran Jawa di daerah asal, di mana mereka pada umumnya berasal dari daerah pedesaan dan berprofesi sebagai petani. Praktik gotong royong dan kerja sama saling membantu baik dalam hubungan sosial ketetanggaan maupun dalam aktivitas pertanian sawah. Salah satu contohnya, merupakan bentuk kerjasama yang melibatkan banyak orang secara sukarela dan tanpa upah dalam kegiatan membuat rumah. Sistem pengerjaan sawah juga dilakukan secara bergotong royong, terutama pada tahap penanaman dan pemanenan. Nilai kebersamaan dan saling membantu dianggap lebih penting atau bernilai tinggi melampaui nilai ekonomi dalam hidup bersama petani.

Dalam nilai gotong royong dan kebersamaan terkandung prinsip hidup bahwa setiap orang atau pihak memiliki kedudukan secara sejajar atau kesetaraan. Tidak menganggap atau menempatkan orang maupun pihak lain dalam posisi lebih rendah menjadi pondasi bagi berlangsungnya tindakan saling tolong menolong dan kerjasama. Perbedaan status dan kelas sosial yang pada realitasnya ada pada sebagian besar masyarakat, dicoba tidak ditunjukkan agar perbedaan kelas tersebut tidak mengganggu 
kebersamaan dan kegiatan yang berlandaskan gotong royong. Prinsip pertukaran yang setara juga mendasari nilai gotong royong, di mana setiap orang wajib membalas bantuan yang diberikan oleh orang lain (bergantian) tanpa melihat status sosialnya.

\section{Munculnya modal sosial dalam kegiatan sosial ekonomi}

Nilai sosial yang menjunjug tinggi kebersamaan dan gotong royong dilestarikan di lokasi transmigrasi. Hal ini dapat dilihat pada dua ruang interaksi, yakni: interaksi dan kerjasama dalam kehidupan sosial di lingkungan tempat tinggal dan pemukiman, dan interaksi serta kerjasama dalam kegiatan ekonomi pengelolaan perkebunan sawit sebagai mata pencaharian pokok para transmigran. Praktik dan pengalaman hidup bersama di lokasi transmigrasi yang dilandaskan pada nilai gotong royong dan saling membantu perlahan-lahan menciptakan kepercayaan antar anggota yang berbeda latar kebudayaan dan mampu membentuk jalinan kerjasama.

Interaksi sosial yang berlangsung dalam kehidupan sosial di Desa Sawit Jaya menyangkut aktivitasaktivitas sosial sebagai warga dalam lingkup ketetanggan, RT, dusun, dan desa. Interaksi antar tetangga ditandai dengan saling menghormati dan adanya kesadaran untuk menjaga diri untuk menghindari konflik. Saling berkunjung sekedar mengobrol atau mengunjungi orang sakit, berbagi makanan, atau memberikan bantuan tenaga ketika tetangga sedang kerepotan merupakan bentuk konkret dari adanya nilai gotong royong dan kebersamaan yang dijunjung tinggi oleh anggota masyarakat. Kegiatan sosial di tingkat RT dan dusun lebih diarahkan untuk kegiatan pemeliharaan infrastruktur jalan atau fasilitas umum di desa, sedangkan kegiatan menyangkut perayaan-perayaan hari besar keagamaan dan nasional dilakukan di tingkat desa. Kegiatan gotong royong dilakukan di tingkat RT maupun di tingkat dusun maupun desa yang dijadwalkan dalam waktu-waktu tertentu. Demikian pula kegiatan keagamaan berupa pengajian untuk ibu-ibu dan bapak-bapak dilakukan secara rutin baik dalam siklus mingguan maupun bulanan. Kegiatan kesenian dilakukan secara terpisah antara orang Jawa dan orang Paser, namun hal ini masih wajar karena mereka memiliki budaya (kesenian) yang berbeda. Kegiatan-kegiatan sosial tersebut merupakan sarana interaksi sekaligus mekanisme untuk mempererat ikatan sosial antar anggota masyarakat.

Stereotipe negatif yang berkembang di antara kelompok etnis tidak ditampakkan ke permukaan di dalam kehidupan sehari-hari, sebaliknya menekankan pada pandangan positif untuk menjaga hubungan sosial. Kesadaran akan peristiwa ketidakadilan terkait redistribusi lahan pada awal program menjadi elemen kontrol tersendiri bagi anggota masyarakat terutama bagi transmigran pendatang, supaya lebih menjaga hubungan baik dengan transmigran lokal. Hal tersebut juga ditunjukkan dalam urusan politik pemilihan kepala desa, di mana warga transmigran pendatang memilih kepala desa yang berasal dari warga lokal meskipun dari sisi jumlah penduduk warga transmigran pendatang dapat memenangkan calon kepala desa yang berasal dari transmigran pendatang. Kesadaran untuk menjaga kebersamaan dan kedamaian benar-benar dijaga oleh kedua belah pihak.

Hal tersebut tidak lepas dari peran pemimpin, terutama tokoh masyarakat lokal yang mampu menjaga hubungan baik dengan seluruh warga tanpa membedakan asal usul daerah. Diberikan ruang sosial yang setara dan adil antara transmigran lokal dan pendatang dalam setiap kesempatan. Tokoh etnis lokal tidak menjadikan ketidakadilan yang pernah terjadi dan potensi konflik yang ada sebagai alat politik yang menyudutkan kelompok pendatang. Pandangan dan sikap bijak tokoh masyarakat lokal yang diikuti oleh seluruh anggota menjadi penguat bagi terbentuknya modal sosial di pemukiman transmigran.

Berbeda dengan interaksi sosial di lingkungan tempat tinggal yang dilandasi nilai gotong royong dan kerjasama yang kuat, interaksi dalam hal ekonomi dan pengelolaan perkebunan sawit plasma menunjukkan pola yang sedikit berbeda. Di satu sisi, hubungan antar petani pada umumnya dilandasi kepercayaan dan tercipta jaringan kerja antar individu petani. Kesamaan mata pencaharian sebagai petani sawit sangat membantu cairnya hubungan antar warga pada awal-awal dimukimkan. Pengalaman dan pengetahuan yang berbeda dalam mengelola lahan antara transmigran lokal dan transmigran Jawa lama kelamaan dipertukarkan menjadi pengetahuan bersama dan pengalaman 
kolektif. Pertukaran informasi, pengalaman dalam mengelola lahan kebun juga menjadi mekanisme yang positif bagi munculnya kepercayaan antar para transmigran.

Kerjasama antar rumah tangga petani terjalin dalam bentuk pertukaran tenaga kerja. Tidak ada hambatan kultural maupun struktural untuk saling mempekerjakan buruh atau tenaga kerja yang berasal dari etnis yang berbeda, antara lokal dan pendatang. Pada umumnya rumah tangga petani membutuhkan tenaga kerja buruh dalam kegiatan pemanenan sawit, sedangkan kegiatan pemupukan tanaman, pembersihan rumput dan gulma pada umumnya dilakukan sendiri oleh petani pemilik. Sudah menjadi hal yang biasa ketika petani lokal mempekerjakan petani transmigran Jawa untuk kegiatan tertentu, ataupun sebaliknya transmigran Jawa mempekerjakan petani lokal.

Jaringan kerjasama dalam bidang penjualan buah sawit dari petani ke tengkulak. Ada beberapa tengkulak yang juga merupakan petani sawit di Desa Sawit Jaya. Pada umumnya hubungan antara petani dengan tengkulak merupakan hubungan patronase, di mana tengkulak sebagai pihak yang memberikan bantuan kepada petani ketika petani sedang mengalami kesulitan keuangan. Tengkulak bukan sekedar orang yang membeli buah sawit, melainkan juga sebagai penolong keuangan bagi petani. Kerjasama yang dilakukan pada umumnya bersifat individual, di mana hubungan kerjasama dilakukan berdasar jaringan personal yang dimiliki oleh masing-masing petani, tanpa membedakan latar belakang suku bangsa. Kerjasama ini dibentuk dengan orientasi mendapatkan keuntungan pribadi atau penyelesaian masalah pribadi. Setiap orang membangun jaringan sosial masing-masing dalam urusan pengelolaan kebun.

Di sisi lain, jaringan kerja dalam pengelolaan perkebunan melalui kelompok tani dan KUD tidak berjalan sebagaimana mestinya. Nilai gotong royong dan kepercayaan antar petani tidak mampu membentuk kerjasama kelembagaan yang lebih luas, dalam hal ini kerjasama dalam kelompok tani dan koperasi. Kondisi ini terjadi karena dalam sejarahnya keberadaan kelompok tani dan koperasi merupakan alat kepanjangan kekuasaan perusahaan inti sebagai pembina petani. Sebagai petani binaan perusahaan, para transmigran diwajibkan oleh perusahaan untuk melakukan kegiatan perkebunan secara bergotong royong, di mana kelompok-kelompok tani dibentuk dari semua petani untuk mengerjakan satu hamparan kebun secara bersama-sama. Kegiatan pembersihan lahan, penanaman, pemeliharaan, hingga pemanenan dirancang untuk dilakukan secara bersama-sama, namun kuatnya intervensi perusahaan pada tahap-tahap awal pembangunan kebun membuat petani kehilangan kedaulatan sebagai pemilik kebun plasma. Intervensi perusahaan dalam pembangunan dan pengelolaan kebun dalam bentuk penerapan aturan yang ketat, upaya mengejar target kerja dan produksi, dan pemberian sanksi selama proses produksi kepada petani, pada gilirannya membuat petani merasa tidak nyaman dan terkekang. Sistem gotong royong melalui kelompok tani yang dipaksakan oleh perusahaan terus merosot dari waktu ke waktu dan akhirnya tidak ada lagi kerjasama secara kelembagaan antar petani sawit. Kelompok tani dan koperasi tidak lagi berperan riil untuk mengkoordinir anggota untuk kegiatan pengelolaan kebun secara bersama.

Dengan demikian tampak bahwa terbentuknya kepercayaan antar transmigran yang dilandasi oleh nilai gotong royong dan kebersamaan tidak mampu membentuk kerjasama ekonomi dalam bentuk kelembagaan atau organisasi petani yang lebih kuat. Kelompok tani dan KUD bentukan perusahaan tidak dirasakan memberikan manfaat yang berarti bagi petani sawit, bahkan sebaliknya sering dirasakan sebagai beban. Berdasar pengalaman petani, kedua lembaga tersebut tidak jarang hanya sebagai kepanjangan tangan kekuasaan perusahaan dan untuk keuntungan perusahaan. Hal ini yang menciptakan kurangnya kepercayaan kepada lembaga atau organisasi.

Ketidakpercayaan anggota kepada lembaga koperasi disebabkan oleh beberapa hal. Pertama, kurangnya kemampuan manajerial dari pengurus koperasi. Pendidikan yang pada umumnya rendah menjadi kendala dalam penyelengaraan administrasi koperasi. Kedua, pengurus koperasi lebih mementingkan kepentingan diri sendiri daripada kepentingan anggota. Selama koperasi beroperasi, banyak terjadi kasus kecurangan yang dilakukan oleh pengurus. Ketiga, lembaga koperasi yang dibentuk secara top down tidak mampu melepaskan campur tangan perusahaan pembina. Ketiga hal tersebut menyebabkan koperasi tidak berkembang menjadi modal bagi kemajuan petani sawit. 


\section{Simpulan}

Potensi konflik yang terjadi dalam masyarakat transmigran bersumber dari penyerobotan lahan milik warga lokal dan redistribusi lahan transmigrasi oleh pemerintah di masa lalu yang dianggap tidak adil oleh warga lokal. Transmigran pendatang dianggap lebih diuntungkan oleh program transmigrasi, sebaliknya warga lokal dirugikan. Perbedaan nilai dan perilaku antar transmigran pendatang dan lokal di lokasi transmigran juga menciptakan stereotipe negatif terhadap satu sama lain. Pengalaman kolektif atas tindakan ketidakadilan oleh pemerintah dan stereotipe negatif antar kelompok merupakan potensi konflik yang dalam kondisi tertentu dapat menjadi konflik terbuka.

Ditinjau dari proses sosial yang terjadi, transmigran lokal dan pendatang mampu membangun interaksi sosial dengan baik. Hal ini terjadi karena keduanya memiliki nilai budaya yang sama yakni menghargai gotong royong, kebersamaan, dan kesejajaran. Landasan nilai tersebut sangat berguna untuk membentuk kepercayaan (trust) sebagai elemen modal sosial yang memungkinkan terjadinya interaksi lebih intensif dan kerjasama. Dalam wilayah ekonomi perkebunan, hubungan individual sebagai sesama petani terjalin dengan baik dilandasi oleh kepercayaan dan kemauan untuk menjalin kerjasama, namun modal sosial dalam urusan pengelolaan perkebunan hanya berlaku sebatas hubungan individual antar petani atau berdasar jaringan individual. Kerjasama dalam bentuk usaha bersama dan ditujukan untuk kemajuan dan manfaat bersama melalui organisasi petani tidak terbentuk. Faktor yang menyebabkan hal itu terjadi adalah adanya intervensi yang terlampau kuat dari perusahaan inti sebagai pembina petani. Hubungan atas bawah, pembina dan dibina, mengindikasikan ketidaksejajaran, di mana hal itu tidak sesuai dengan nilai-nilai para petani sawit.

\section{Daftar Pustaka}

Ahimsa HS (2012) Fenomenologi agama: pendekatan fenomenologi untuk memahami agama. Jurnal Walisongo 20 (2):271-304.

Ahmadi S (2003) Perkembangan ekonomi komunitas orang Madura di Sumbawa, NTB. Masyarakat, Jurnal Sosiologi 12:4-26.

Clauss W, Evers HD, \& Gerke S (1988) The formation of a peasant sociaety: Javanese transmigrants in East Kalimantan. Indonesia 46:78-90.

Dove MR (1988) Sistem Perladangan di Indonesia: Suatu Studi Kasus dari Kalimantan Barat. Yogyakarta: Gadjah Mada University Press.

Fauzi N (1999) Petani dan Penguasa, Dinamika Perjalanan Politik Agraria Indonesia. Yogyakarta: INSIST,KPA, dan Pustaka Pelajar.

Fukuyama F (2002) Trust: Kebajikan Sosial dan Penciptaan Kemakmuran. Yogyakarta: CV. Qalam Yogyakarta.

Li TM (2002) Keterpinggiran, Kekuasaan, dan Produksi: Analisis terhadap Transformasi Daerah Pedalaman. Dalam Proses Transformasi Daerah Pedalaman di Indonesia. Penyunting: Li TM. Jakarta: YOI.

N.N. (2012) Mahasiswa toraja demo tolak transmigrasi. [Diakses 15 Oktober 2016]. http://regional.kompas.com/read/012/09/17/20283880/Mahasiswa-Toraja-Demo-TolakTransmigrasi.

N.N. (2015) Ratusan mahasiswa demo tolak program transmigrasi di kalbar. [Diakses 15 Oktober 2016]. http://indonesia. ucanews.com/2015/05/20/ratusan-mahasiswa-tolak-transmigrasi-dikalimantan/.

N.N. (2015) Konsep transmigrasi baru ke kalimantan dan papua ditolak. [Diakses 15 Okober 2016]. http://sp.beritasatu.com/home/konsep-transmigrasi-baru-ke-kalimantan-dan-papuaditolak/87897/25 Mei.

N.N. (2016) Forum Perbatasan Tolak Transmigrasi. [Diakses 15 Oktober 2016]. http://www.pontianakpost.co.id/forum-perbatasan-tolak-transmigrasi. 
Singarimbun M (1994) Hak ulayat masyarakat adat. Dalam: Florus P, Djuweng S, Bamba J \& Andasputra N (eds) Kebudayaan Dayak: Aktualisasi dan Transformasi. Jakarta: LP3ES, IDRD, PT Grasindo.

Wafa A (2003) Urgensi keberadaan sosial capital dalam kelompok-kelompok sosial: Kajian mengenai sosial kapital pada kelompok tani Mardi Utomo dan kelompok PKK di Desa Bakalan, Kecamatan Jumapolo, Kabupaten Karanganyar, Jawa Tengah. Masyarakat Jurnal Sosiologi 12:28-40.

Wibowo LR, Runggandini C \& Subarudi (2008) Konflik Sumber Daya Hutan dan Reforma Agraria, Kapitalisme Mengepung Desa. Yogyakarta: Alfamedia. 